\title{
Securities Law and the Constitution: State Tender Offer Statutes Reconsidered
}

Thirty-six states ${ }^{1}$ have enacted statutes that regulate tender offers ${ }^{2}$ for corporations maintaining certain contacts with the regulating state. $^{3}$ Tender offers are also subject to federal regulation under the Williams Act; ${ }^{4}$ thus, an offeror may have to satisfy both state and federal requirements before proceeding with an offer. This two-tier system of tender offer regulation is necessary, according to proponents of the state laws, in order to protect fully the shareholders of the target $^{5}$ company. $^{6}$

There has been almost universal agreement among commentators, ${ }^{7}$

1. See notes 28 \& 29 infra (listing statutes).

2. A tender offer is conventionally defined as a public solicitation of the shareholders of a corporation to tender their shares to the offeror at a specified price, see E. ARANow \& H. Einhorn, Tender Offers for Corporate Control 70 (1973); Note, The Developing Meaning of "Tender Offer" Under the Securities Exchange Act of 1934, 86 HARv. L. REv. 1250, 1251-52 (1973), although more expansive definitions have been employed, see Cattlemen's Inv. Co. v. Fears, 343 F. Supp. 1248 (W.D. Okla. 1972); E. Aranow, H. Einhorn \& G. Berlstein, Developments in Tender Offers for Corporate Control 1-34 (1977); Note, supra, at 1275-81. For an analysis of the mechanics and tactics of a tender offer, see E. Aranow \& H. Einhorn, supra, at 10-63, 219-76; A. Fleischer, Tender Offers: Defenses, Responses and Planning (1978); 1 J. Flom, M. Lipton \& E. Steinberger, Takeovers and Takeouts-Tender Offers and Going Private 9-107 (1976); Fleischer \& Mundheim, Corporate Acquisition by Tender Offer, 115 U. PA. L. REv. 317 (1967).

3. See p. 515 infra.

4. 15 U.S.C. $\$ \S 78 l(\mathrm{i}), 78 \mathrm{~m}(\mathrm{~d})-(\mathrm{e}), 78 \mathrm{n}(\mathrm{d})-(\mathrm{f})(1976)$.

5. The target company is the corporation the securities of which are or will soon be the subject of a tender offer. See N.Y. Bus. CoRP. Law $\$ 1601$ (e) (McKinney Supp. 1978). For a discussion of the characteristics of a potential target company, see E. ArANow \& $\mathrm{H}$. Einhorn, supra note 2, at 1-9.

6. See, e.g., Shipman, Some Thoughts About the Role of State Takeover Legislation: The Ohio Takeover Act, 21 CASE W. REs. L. REv. 722, 723 (1970); Vorys, Ohio Tender Offers Bill, 43 OHIO B. 65 (1970). Several commentators have explained that the Williams Act did little to restrain high pressure tender offers, known as "blitzkriegs" or "Saturday Night Specials," even though such offers "effectively deprived both management and stockholders of the target company of the opportunity to respond intelligently" to a tender offer .... and that shareholders were being stampeded to accept questionable or inadequate offers because there was often insufficient time to obtain a higher offer." Arsht, The Delaware Takeover Statute-Special Problems for Directors, 32 Bus. LAw. 1461, 1461 (1977); see Bartell, The Wisconsin Takeover Statute, 32 Bus. LAw. 1465, 1466 (1977); Robinson, Directors Under Attack in New 'Bear Hug' Mergers, N.X.L.J., June 12, 1978, at 41 , col. 1 .

7. E.g., Langevoort, State Tender Offer Legislation: Interests, Effects and Political Competency, 62 Cornell L. Rev. 213 (1977); Wilner \& Landy, The Tender Trap: State 
however, that most of these state laws are both preempted by the Williams Act and repugnant to the commerce clause of the Constitution. ${ }^{8}$ In Great Western United Corp. v. Kidwell, ${ }^{9}$ the Fifth Circuit recently relied on both of these arguments and invalidated the Idaho tender offer statute. ${ }^{10}$ This is particularly significant since it is the first case in which a federal court has ruled on the constitutionality of a state tender offer law. Consequently, the decision casts serious doubt on the validity of the thirty-five other state tender offer statutes.

This Note reevaluates the constitutionality of the state tender offer laws. Its basic premise is that both courts and commentators have been too quick to conclude that the state laws are preempted, or wholly void under the commerce clause. The Note argues that the state tender offer laws are not preempted by the Williams Act. This conclusion is based, in part, on Piper v. Chris-Craft Industries, Inc., ${ }^{11}$ in which the Supreme Court stated that the sole purpose of the Williams Act is investor protection. The state laws are entirely consistent with this purpose and thus are not preempted by the federal legislation. The Note also demonstrates that although the state statutes do impose some improper burdens on interstate commerce, many of the features of these laws represent responses to valid state concerns and do not conflict with the commerce clause. The Note proposes an analysis that assesses the individual components of these laws and their effects on the tender offer process, and concludes that certain modifications should be made so that the state statutes can continue to fulfill their intended role within the limitations of the commerce clause.

Takeover Statutes and Their Constitutionality, 45 FordHAM L. REv. 1 (1976); Note, Commerce Clause Limitations upon State Regulation of Tender Offers, 47 S. CAL. L. REv. 1133 (1974). Mfuch of this literature seems to be prompted by opposition to the state laws on policy grounds.

8. The preemption doctrine is derised from the supremacy clause of the Constitution: "This Constitution, and the Laws of the United States which shall be made in Pursuance thereof; ... shall be the supreme Law of the Land; and the Judges in every State shall be bound thereby, any Thing in the Constitution or Laws of any State to the Contrary notwithstanding." U.S. CoNst. art. VI, $\$ 2$; see, e.g., Rice v. Santa Fe Elevator Corp., 331 U.S. 218 (1947); The Federalist No. 32 (A. Hamilton). See generally G. Gunther, Cases and Materials on Constitutional. Law 357-67 (9th ed. 1975).

The commerce clause provides that " $[\mathrm{t}] \mathrm{he}$ Congress shall have Power . . . To regulate Commerce with foreign Nations, and among the several States." U.S. CoNst. art. I, § 8, cl. 3; see, e.g., H.P. Hood \& Sons v. Du Mond, 336 U.S. 525 (1949). See generally G. GUNTHER, supra, at 278-356.

9. 577 F.2d 1256 (5th Cir. 1978) (aff'g 439 F. Supp. 420 (N.D. Tex. 1977)). For discussion of the lower court's opinion, see Balotti, The Delaware Tender Offer Statute, 3 Del. J. Corp. L. 230 (1978); Note, Supremacy and Commerce Clause Limitations on State Regulation of Tender Offers, 42 ALB. L. REv. 492 (1978).

10. InAHo CoDE $\$ \$ 30-1501$ to -1513 (Supp. 1978).

11. 130 U.S. 1 (1977). 


\section{The Scope of Tender Offer Legislation}

Those who claim that the state laws are invalid assert that they conflict with the objectives of the federal Williams Act and impermissibly obstruct the making of tender offers. Supporters of the state statutes, on the other hand, argue that the laws merely supplement the minimum requirements imposed by the William Act. Thus, it is appropriate to consider the federal response to tender offers and then outline the operation of the state acts before turning to the constitutional questions.

\section{A. The Williams Act}

The Williams Act amendments to the Securities Exchange Act of $1934^{12}$ were adopted in order to assist investors confronted with a cash tender offer in making an informed decision about whether to tender their shares. ${ }^{13}$ Proponents of the Williams Act claimed that a shareholder of a target company required extensive information about the terms and conditions of the offer and the identity and plans of the offeror; without such information, it was argued, the shareholder could not make an educated choice between tendering his stock at the offered price or refusing the offer and assuming the risk of a possible change in corporate control. ${ }^{14}$ Prior to the passage of the Act in 1968, the cash tender offeror was not required to disclose either its identity or its plans. ${ }^{15}$ The enactment of the Williams Act closed this significant gap in the disclosure requirements of the federal securities laws. ${ }^{16}$

12. 15 U.S.C. $\$ \S 78 \mathrm{a}-78 \mathrm{kk}(1976)$.

13. See Rondeau v. Mosinee Paper Corp., 422 U.S. 49, 58 (1975); Full Disclosure of Corporate Equity Ownership and in Corporate Takeover Bids: Hearings on 5510 Before the Subcomm. on Securities of the Senate Comm. on Banking and Currency, 90th Cong., Ist Sess. 188 (1967) [hereinafter cited as Hearings]; S. REP. No. 550, 90th Cong., Ist Sess. 2-4 (1967).

14. See Cohen, A Note on Takeover Bids and Corporate Purchases of Stock, 22 Bus. LAw. 149, 150-52 (1966). Cohen, then chairman of the Securities and Exchange Commission, testified before the Senate Subcommittee on Securities and emphasized the need for legislation to "provide the investor, the person who is required to make a decision, an opportunity to examine and to assess the relevant facts." Hearings, supra note 13, at 15.

15. Although proxy contests for corporate control were regulated by $\S 14$ (a) of the Securities Exchange Act of 1934, 15 U.S.C. $\$ 78 \mathrm{n}(\mathrm{a})$ (1976), and exchange offers were subject to the registration requirements of the Securities Act of 1933, 15 U.S.C. \$\$ 773$77 \mathrm{~h}, 77 \mathrm{j}$ (1976), cash tender offers remained conspicuously outside the ambit of federal securities regulation. See H.R. REP. No. 1711, 90th Cong., 2d Sess. 4, reprinted in [1968] U.S. Code Cong. \& Ad. News 2811, 2814; S. ReP. No. 550, 90th Cong., 1st Sess. 3 (1967); Sowards \& Mofsky, Corporate Take-Over Bids: Gap in Federal Securities Regulation, 41 Sr. JohN's L. REv. 499 (1967).

16. See S. REP. No. 550, 90th Cong., 1st Sess. 4 (1967) (Williams Act will "correct the current gap in our securities laws"). 
The most important provisions of the Williams Act are those now codified in sections $13(\mathrm{~d})^{17}$ and $14(\mathrm{~d})^{18}$ of the Securities Exchange Act. Both are intended to provide shareholders with the information necessary to evaluate the merits of a tender proposal. These sections require detailed and timely disclosures both when significant acquisitions by an individual or group increase the possibility of a takeover attempt and when an actual tender offer is made. Section 13(d) requires that within ten days after acquiring beneficial ownership of five percent of any class of equity securities registered under Section 12 of the Securities Exchange Act, ${ }^{19}$ a person must file a Schedule $13 \mathrm{D}^{20}$ with the Securities and Exchange Commission (SEG). The Schedule 13D must disclose inter alia: the purchaser's identity and background; the amount and source of funds for the purchase; the extent of the purchaser's holdings in the target; and, if the purpose of the purchases is to acquire control of the corporation, any plans to liquidate, merge, or make any other major changes in the target's business or corporate structure.

Section 14(d) provides that a person making a formal tender offer must file a Tender Offer Statement Schedule 14D-121 and publish or send to the shareholders of the target corporation the relevant facts it contains. The Schedule 14D-1 includes the same information as the Schedule 13D and requires additional information regarding the offeror's source of funds and its plans or proposals, disclosure of any past negotiations or transactions with the target company, and financial information about the offeror when such information is material to the offer. ${ }^{22}$ The offeror must also disclose any antitrust or other legal conflicts relating to the tender offer if such information would be material to the target company's shareholders in deciding whether to tender their shares. ${ }^{23}$

In addition to these disclosure provisions, the Act attempts to assist

17. 15 U.S.C. $\$ 78 \mathrm{~m}(\mathrm{~d})(1976)$.

18. $I d . \S 78 \mathrm{n}(\mathrm{d})$.

19. A corporation with assets of at least $\$ 1,000,000$ and over 500 shareholders and any corporation whose securities are traded on a national exchange must register under $\S 12$. Securities Exchange Act of 1934, § 12, 15 U.S.C. $\$ 78 l$ (1976).

20. 17 C.F.R. $\$ 240.13 \mathrm{~d}-101$ (1977).

21. 42 Fed. Reg. 38,341 (1977) (to be codified in 17 C.F.R. $\$ 240.14 d-100$ ).

22. Section 14(e) of the Williams Act, 15 U.S.C. $\$ 78 \mathrm{n}(\mathrm{c})$ (1976), requires the offeror to disclose all other material facts. For a discussion of materiality in the context of a proxy contest, see TSC Indus., Inc. v. Northway, Inc., 426 U.S. 438, 449 (1976) ("An omitted fact is material if there is a substantial likelihood that a reasonable shareholder would consider it important in deciding how to vote.")

23. 42 Fed. Reg. 38,341 (1977) (to be codified in 17 C.F.R. $\$ 240.14 d-100$ ). The target company is subject to the disclosure requirements of the Williams Act if it attempts to persuade its shareholders either to accept or to reject the offer or if it purchases its own shares during the course of the tender offer. 17 C.F.R. $\$ 240.14 d-4$ (1977). 
tendering shareholders by providing them with certain substantive protections during the course of the offer. It requires that tendering shareholders be permitted to withdraw their tendered stock ${ }^{24}$ during the first seven days following publication of the offer, or after sixty days if the offeror has not already purchased the tendered shares. ${ }^{25}$ In addition, if the offer is for less than $100 \%$ of the target's shares, all shares tendered during the first ten days must be purchased on a pro rata rather than a first-come, first-served basis. ${ }^{26}$ Finally, any subsequent increase in the offered price must also be paid to those shareholders who have already tendered their stock. ${ }^{27}$

\section{B. State Regulation}

Virginia enacted the first state tender offer statute in March 1968, four months prior to the passage of the Williams Act. ${ }^{28}$ Thirty-five states have followed suit, ${ }^{29}$ adopting laws that impose tender offer

24. A tendering shareholder must deliver his shares together with a properly executed "Letter of Transmittal" to the offeror's designated depositary or forwarding agent. The Letter of Transmittal, which is drafted by the offeror, requires the shareholder to represent that he can lawfully sell the shares and that the offeror will acquire clear and unrestricted title. In addition, the offeror often requires: identification of the tendered shares by their certificate numbers, the name and address of the shareholder and instructions for payment of the purchase price or return of any shares not accepted, the signature of the registered owner, and the signature of the authorized guarantor when the tender does not occur simultaneously with the deposit of the share certificates. See E. Aranow \& H. EinhCRN, supta note 2, at 59-60.

25. Williams Act $\S 14(\mathrm{~d})(5)$, 15 U.S.C. $\$ 78 \mathrm{n}(\mathrm{d})(5)$ (1976).

26. Id. $\$ 14(\mathrm{~d})(6)$, 15 U.S.C. $\$ 78 \mathrm{n}(\mathrm{d})(6)(1976)$. The Williams Act does not explicitly require the offer to remain open for any length of time. However, it effectively creates a 7- to 10-day minimum offering period by providing that all tendered shares may be withdrawn during the first 7 days of the offer and that all shares tendered during the first 10 days must be purchased on a pro rata basis. The Antitrust Improvements Act, 15 U.S.C. $\$ 18 a(1976)$, requires that certain offers remain open for 15 days and that certain others remain open for 30 days.

27. Williams Act $\$ 14(d)(7)$, 15 U.S.C. $\$ 78 \mathrm{n}(\mathrm{d})(7)(1976)$.

28. VA. Code $\$ \$ 13.1-528$ to -541 (1978) (effective Mar. 5, 1968).

29. Alaska Stat. \$\$ 45.57.010-.120 (Supp. 1978); ARK. Stat. ANN. \$S 67-126t to 1264.14 (Supp. 1977); Colo. Rev. STAT. SS 11-51.5-10I to -108 (Supp. 1976); ConN. GeN. Stat. \$§ 36-347a to $-347 m$ (1977); Del. Code ANN. tit. 8, \$ 203 (Supp. 1977); FLA. STAT. ANN. $\$ \$ 517.35$ to .36 (Supp. 1978); GA. CODE ANN. $\$ \$$ 22-1901 to -1915 (I977); Haw.MI REv. Stat. $\$ \$ 417 E-1$ to -15 (1976); IdAHo Code $\$ \$ 30-1501$ to -1513 (Supp. 1978); Act of Sept. 8, 1977, Pub. Act 80-556, ILL. ANN. Sr.1T. ch. 1211/2, \$ 137.5-1 (Smitl1-Hurd Supp. 1978); IND. Code ANn. $\$ \$ 23-2-3-1$ to -12 (Burns Supp. 1978); Iowa Uniform Securities Act $\$ \$$ 502.102, .211-.215 (1978), reprinted in 1A BLUE SKY L. REP. (CCH) (C 18,142, 18,161-165; Kan. Stat. ANN. $\$ \$ 17-1276$ to -1285 (1974); Ky. Rev. Stat. $\$ \$ 292.560-.991$ (Supp. 1978); LA. Rev. Stat. ANn. $\$ \$$ 51:1500-:1512 (West Supp. 1978); Me. Rev. Stat. ANN. tit. 13, $\$ 801-817$ (Supp. 1978); MD. CoRP. \& Ass'Ns CODE ANN. $\$ \$ 11-901$ to -908 (Supp. 1977); Mass. Ans. Laws ch. 110C, $\$ \$ 1$ 1-13 (Michie/Law. Co-op Supp. 1978); Mich. Comp. Laws AN. $\$ \$ 451.901-.917$ (Supp. 1978); Mins. ST.AT. ANN. \$\$ 80B.01-.13 (West Supp. 1977); Miss. Code AnN. $\$ \$ 75-72-1$ to -23 (Supp. 1978); Mo. Take-Over Bid Disclosure Act, 1978 Mo. Laws S.B. No. 820, reprinted in 2 Blue SKY L. REP. (CCH) CC 28,201-214; Neb. Rev. Stat. $\$ \$ 21-2401$ to -2417 (1977); Nev. Rev. Stat. $\$ \$ 78.376$ to -.3778 (1973); N.H. REv. 


\section{Tender Offer Statutes}

regulations that often differ from those prescribed by the Williams Act. The purpose of these acts is generally claimed to be to provide protection to shareholders of target companies in addition to that provided by federal tender offer regulations. ${ }^{30}$

Although the state acts often vary significantly in their terms, it is nevertheless possible to outline their general characteristics. ${ }^{31}$ Nearly all of the state laws regulate tender offers for corporations incorporated under the laws of the state and most apply to offers for corporations that have substantial assets or a principal place of business in the state. $^{32}$ If the target company comes within the statutory jurisdictional requirements, the offeror is subject to the regulating state's law in its transactions with shareholders living both inside and outside the state. ${ }^{33}$ This extraterritorial effect is designed to prevent the offeror from circumventing the requirements of a particular state by omitting the residents of that jurisdiction from the offer. ${ }^{34}$

The acts typically impose both disclosure and substantive requirements on the offeror. Some state statutes require the offeror to supply the applicable securities agency with information similar to that disclosed in the Schedule 13D filed under the Williams Act. ${ }^{35}$ Several

Stat. ANN. $\S \S 421$-A:1 to :15 (1977); N.J. Stat. ANN. $\$ \S 49: 5-1$ to -19 (West Supp. 1978); N.X. Bus. CoRP. LAw $\$ \S 1600-1613$ (McKinney Supp. 1978); N.C. GeN. STAT. $\$ \$ 78 B-1$ to -11 (Supp. 1977); Ohio Rev. Code Ann. \$ 1707.041 (Page 1978); 70 Pa. Cons. Stat. Ann. $\$ \S 71-85$ (Purdon Supp. 1978); S.D. Comp. LAws ANn. $\$ \$ 47-32-1$ to -47 (Supp. 1978); Tenn. Code ANN. $\$ \S 48.2101$ to -2114 (Supp. 1978); Utah CODE ANN. $\$ \$ 61-4-1$ to -13 (1978); Wis. Stat. ANn $\$ \S 552.01-.25$ (West Special Pamphlet 1978); Tex. Administrative Guidelines for Minimum Standards in Tender Offers 065.15.00.100-.800, reprinted in 3 Blue SKY L. REP. (CCH) \& 46,615.

30. The Ohio General Assembly, for example, declared that the purpose of the Ohio law is "[t]o protect shareholders of Ohio and Ohio based corporations by requiring public announcement and fair, full, and effective disclosure to shareholders in regard to takeover bids." 1969-70 Ohio Laws 352 (1969) (statute codified at OHo REv. Code ANN. $\$ 1707.041$ (Page 1978)).

31. See generally E. Aranow, H. Einhorn \& G. Berlstein, supra note 2, at 207-17; Langevoort, supra note 7, at 219-40; Vaughan, State Tender Offer Regulation, 9 REv. SEC. REG. 969 (1976); Wilner \& Landy, supra note 7, at 3-9.

32. See E. Aranow, H. Einhorn \& G. Beristein, supra note 2, at 234-36 (table of state statutes indicating jurisdictional requirements). Compare Del. CodE ANN. tit. 8, § 203(c)(2) (Supp. 1977) (incorporated in state) with N.J. STAT. ANN. \$ 49:5-2m (West Supp. 1978) (incorporated or principal place of business or substantial assets in state) and N.Y. Bus. CoRp. LAw $\$ 1601$ (a) (McKinney Supp. 1978) (incorporated, or principal place of business and substantial assets in state).

33. E.g., Idaho Cone $\$ 30-1506(1)$ (Supp. 1978); Kan. Stat. ANN. $\$ 17-1278$ (1974) (both requiring that tender offer be made to regulating state's shareholders on same terms offer is made to shareholders living in other states). See generally E. ARANOw \& H. EINHORN, supra note 2, at 161-62.

34 . If a state only regulated offers made to its residents, an offeror could avoid complying with the state's takeover regulations by not soliciting shareholders in that state. See note 110 infra; E. ARANow \& H. EINHORA, supra note 2, at 157.

35. E.g., Colo. Rev. Stat. § 11-51.5-104 (Supp. 1976); Mo. CoRp. \& Ass'ns Code ANn. $\$ 11-902$ (Supp. 1977) (both requiring offeror to file same information disclosed under Williams Act). 
states, however, require much more extensive disclosures. ${ }^{36}$ These filings must be made anywhere from $\operatorname{ten}^{37}$ to sixty ${ }^{38}$ days before the offer can become effective, thus affording the target company's management advance notice of the impending takeover bid. ${ }^{39}$ In addition, the state agency that regulates securities is usually empowered to order a hearing on its own motion and, in many instances, must do so at the request of the target. ${ }^{40}$ The majority of states limit such hearings to the issue of whether an offeror has made full and fair disclosure; ${ }^{41}$ however, several statutes also allow questions of an offer's substantive fairness to be raised before the securities agency. ${ }^{42}$ If an offeror has failed to satisfy the state's requirements, he may be enjoined from proceeding with the offer. ${ }^{43}$

The state statutes, like the Williams Act, also address the substantive terms of the tender offer. The statutes impose various requirements as to the minimum and maximum offering period, 44 the withdrawal rights of tendering shareholders, ${ }^{45}$ and the time during which an offeror must accept all shares tendered on a pro rata basis. ${ }^{46}$

36. New York, Ohio and Pennsylvania, for example, require an offeror to make disclosures concerning its capital structure, any pending legal or administrative proceedings involving the offeror or any of its subsidiaries, and its financial statements for the current and three preceding years. N.X. Bus. CoRP. LAW $\$ 1603$ (McKinney Supp. 1978); OHIO Rev. Code Ann. $\$ 1707.041$ B(3) (Page 1978); 70 PA. Cons. Stat. ANn. $\$ 75$ (Purdon Supp. 1978); see E. ArAnow, H. Einhorn \& G. Berlstein, supra note 2, at 212-13, 219.

37. E.g., Colo. Rev. Stat. \$ 11.51.5-104(1) (Supp. 1976).

38. E.g., Hawail Rev. Stat. $\$ 417 E-3(f)$ (1976). Most states require a 20-day waiting period. See, e.g., N.Y. Bus. Corp. LAw \$ 1602 (McKinney Supp. 1978); OHo Rev. Code ANN. \$ 1707.041(B)(I) (Page 1978).

39. E. ARanow, H. Einhorn \& G. Berlstein, supra note 2, at 217.

40. E.g., Conn. Gen. Star. \$ 36-347e (1977); Idaho Code \$ 30-1503(4) (Supp. 1978). The right to demand a hearing allows management to postpone further the effective date of the offer. See E. Aranow, H. Einhorn \& G. Berlstein, supra note 2, at 217-18, 220.

41. E.g., 70 Pa. Cons. Stat. ANN. \$ 74(d) (Purdon Supp. 1978); see E. Aranow, H. EINHORN \& G. BERLSTEIN, supra note 2, at 216.

42. E.g., N.J. Stat. AnN. § 49:5.4 (West Supp. 1978); Wis. Stat. AnN. § 552.05(5) (West Special Pamphlet 1978).

43. See, e.g., Ohio v. Imetal, Inc., No. 75 Civ. 09.3868 (C.P. Franklin County, Ohio Oct. 9, 1975) (temporary restraining order issued at request of Ohio Division of Securities); E. Aranow, H. Einhorn \& G. BerLstein, supra note 2, at 216-17.

44. E.g., Del. Code ANN. tit. 8, \$ 203(a)(2) (Supp. 1977) (20-day minimum, no maximum); Mich. CoMp. LAws ANN. $\$ 451.905(2)$ (Supp. 1978) (60-day minimum, no maximum); VA. CODE \$ 13.1-530(a) (1978) (21-day minimum, 35-day maximum); see E. ARANow, H. EINHORN \& G. BerLstein, supta note 2, at 213-14.

45. E.g., Colo. Rev. Stat. \$ 11-51.5-103(1)(c) (Supp. 1976) (during first 15 days and after 35 days from announcement of offer); DEL. CODE ANN. tit. 8, $\$$ 203(a)(3) (Supp. 1977) (during first 20 days of offer); N.J. STAT. ANN. $\$$ 49:5-9a (West Supp, 1978) (until three days prior to announced termination of offer); see E. Aranow, H. Einhorn \& G. BertsteIn, supra note 2, at 214-15.

46. E.g., Del. Code ANN. tit. 8, \$ 203(a)(3) (Supp. 1977); Idaho Code \$ 30-1506(3) (Supp. 1978) (during first 10 days of offer); IND. CODE ANN. $\$ 23-2-3-5(b)$ (Burns Supp. 1978) 


\section{Statutory Preemption}

It is often claimed that the state tender offer statutes purposely impose a variety of burdens on offerors in an attempt both to discourage takeover bids for local companies and to protect incumbent management. ${ }^{47}$ The additional disclosure requirements, it is argued, represent a burden in themselves. ${ }^{48}$ Moreover, the state acts greatly increase the possibilities of delaying the initiation of an offer. ${ }^{49}$ Delay redounds to the benefit of the target company's management by depriving the offeror of the advantage of surprise and by providing the target with time to take action to resist the offer..$^{50}$ Finally, the additional requirements imposed by the state acts expand the number of legal grounds on which an offer can be resisted. ${ }^{51}$ The hearing procedures in some state acts are regarded as particularly onerous for offerors because they can lead to long delays and because they can provide a target with a convenient forum for raising various objections. ${ }^{52}$

The burdens that the state statutes impose on offerors create a serious possibility that the acts are preempted by the Williams Act. Commentators have asserted that the state acts are decidedly promanagement because they fail to balance the competing interests of the offeror and the target's management; thus the acts may conflict with

(during entire offer); see E. ArAnow, H. Einhorn \& G. BerLSTEIN, supra note 2, at 215. Hawaii requires that any offer must be for $100 \%$ of the outstanding shares of the target, thus eliminating the need for any pro-rata purchase provisions. Hawall Rev. Stat. $\S 417 \mathrm{E}-2(3)$ (1976).

47. See Corporate Takeovers: Hearings Before the Senate Comm. on Banking, Housing i Urban Affairs, 94th Cong., 2d Sess. 94 (1976) (statement of SEC Commissioner Loomis) [hereinafter cited as Loomis Testimony]; Wilner \& Landy, supra note 7, at 18-19; Note, supra note 7 , at 1159 . The Kentucky bill specifically stated this purpose: "An Act relating to the prevention of take-over bids through the purchase of corporate securities." 1976 Ky. Acts 534 (statute codified at KY. Rev. STAт. $\$ \$ 292.560-.630$ (Supp. 1976)).

48. See Brudney, $A$ Note on Chilling Tender Solicitations, 21 Rutrers L. Rev. 609, 624 (1967) ("The very process of providing additional information operates-and is intended to operate-to increase the cost and to diminish the chances of success of the outside bidder, by enhancing the opportunity for incumbents to divert tenders from him.")

49. See Great Western United Corp. v. Kidwell, 577 F.2d 1256, 1278 (5th Cir. 1978); E. Aranow, H. Einhorn \& G. Beristein, supra note 2, at 217-18, 220. See generally Langevoort, supra note 7 , at 238.

50. The target company's management can resist the tender offer in a variety of ways. The company may recommend that shareholders reject the offer, issue shares to friendly persons, purchase its own shares, increase the dividend paid, declare a stock dividend, commence litigation against the offeror, make an acquisition that crcates antitrust or regulatory problems, or seek out a defensive merger or competing tender offer. I J. FLos, M. Lipton \&: E. Steingerger, supra note 2, at 94-107.

51. See E. Aranow, H. Einhorn \& G. Berlstein, supra note 2, at 220 . See generally Wachtell, Special Tender Offer Litigation Tactics, 32 Bus. LAw. 1433 (1977).

52. See E. ARANow, H. EINHORN \& G. BERLsteIN, supra note 2, at 215-18; Langevoort, supra note 7, at 231-32; Wilner \& Landy, supra note 7, at 9-10. 
the federal policy of even-handed regulation. ${ }^{53}$ In Kidwell the court sounded a similar note, holding that the Idaho statute was preempted because it disrupted the neutrality of federal tender offer legislation. ${ }^{j 4}$

Preemption, however, is a highly complex issue; a careful, detailed analysis of both the federal and state regulatory schemes is required before a state act can be held to be preempted. This is particularly true in light of recent decisions by the Supreme Court. The Court has been highly solicitous of state interests when considering preemption questions. ${ }^{55}$ It has also exhibited a tendency to limit federal involvement in the specific field of securities and corporate law. ${ }^{56}$ As a result, courts and commentators should be much more hesitant in declaring that widely enacted securities statutes like the state tender offer acts are preempted by federal legislation.

The tests that a court should apply in determining whether a state act is preempted by parallel federal legislation are well established.57 First, a state statute will be preempted if Congress has expressly declared its intent to exclude the states from a particular area of regulation. ${ }^{58}$ Second, a state law will be invalidated if a congressional intent to preempt parallel state regulation can be inferred. ${ }^{59} \mathrm{~A}$ court will infer preemptive intent if the federal regulation is so pervasive that it leaves no room for state supplementation, ${ }^{60}$ or if the federal interest in a field

53. E.g., Loomis Testimony, supra note 47; Langevoort, supra note 7, at 246-54; Note, supra note 7, at 1167-70; see Great Western United Corp. v. Kidwell, 439 F. Supp. 420, 437 (N.D. Tex. 1977), aff'd, 577 F.2d 1256 (5th Cir. 1978).

54. Great Western United Corp. v. Kidwell, 577 F.2d 1256, 1279.80 (5th Cir. 1978); see note 81 infra (discussing Fifth Circuit's holding).

55. See, e.g., Kewanee Oil Co. v. Bicron Corp., 416 U.S. 470 (1974) (Ohio trade secret law not preempted by federal patent law); Merrill Lynch, Pierce, Fenner \& Smith, Inc. v. Ware, 414 U.S. 117 (1973) (stock exchange employment termination rule enacted pursuant to Securities Exchange Act of 1934 does not preempt conflicting California statute); Note, The Preemption Doctrine: Shifting Perspectives on Federalism and the Burger Court, 75 Colum. L. Rev. 623, 639-54 (1975).

56. See, e.g., Santa Fe Indus., Inc. v. Green, 430 U.S. 462 (1977) (breach of fiduciary duty by majority shareholders does not violate $\$ 10 \mathrm{~b}$ of Securities Exchange Act of 1934); Blue Chip Stamps v. Manor Drug Stores, 421 U.S. 723 (1975) (private damages action under SEC Rule 10b-5 confined to actual purchasers or sellers of securities). In Santa $F e$, the Court declared that "[a]bsent a clear indication of congressional intent, we are reluctant to federalize the substantial portion of the law of corporations that deals with transactions in securities." 430 U.S. at 479.

57. But see Note, A Framework for Preemption Analysis, 88 Yale L.J. 363 (1978).

58. See Rice v. Santa Fe Elevator Corp., 331 U.S. 218 (1947) (Federal Warehouse Act expressly preempts all concurrent state regulation).

59. See Florida Lime \& Avocado Growers, Inc. v. Paul, 373 U.S. 132, 146-52 (1963); Hirsch, Toward A New View of Federal Preemption, 1972 U. ILL. L.F. 515, 529-33; Note, Pre-emption as a Preferential Ground: $A$ New Canon of Construction, 12 STAN. L. REv. 208-10 (1959).

60. See City of Burbank v. Lockheed Air Terminal, Inc., 411 U.S. 624 (1973) (pervasive federal regulation of aircraft noise preempts local noise controls); Cloverleaf Butter Co. v. Patterson, 315 U.S. 148 (1942) (pervasive federal control of renovated butter preempts concurrent Alabama regulation). 
is so dominant that the states must be precluded from enforcing laws on the same subject. ${ }^{61}$ Third, even in the absence of express or inferred preemption, federal legislation will preempt any concurrent state regulation that "stands as an obstacle to the accomplishment and execution of the full purposes and objectives of Congress." 62 There are thus three recognized types of preemption: explicit, implicit, and operational.

\section{A. Explicit and Implicit Preemption}

A careful application of these principles reveals that the state statutes are not preempted by the Williams Act. Congress has not explicitly indicated an intent to preempt state regulation of tender offers either in the Williams Act or in its legislative history. ${ }^{63}$ In the absence of any such explicit congressional declaration, preemptive intent may be inferred from the pervasiveness of the federal regulatory scheme. ${ }^{84}$ But the Williams Act is not analogous to those comprehensive federal statutes that have been held to preempt parallel state legislation. ${ }^{65}$ The

61. See Pennsylvania v. Nelson, 350 U.S. 497 (1956) (alternative holding) (dominant federal interest in sedition and national security precludes Pennsylvania sedition law); Hines v. Davidowitz, 312 U.S. 52 (1941) (controlling federal interest in foreign affairs creates presumption of federal preemption of Pennsylvania alien registration act).

62. Hines v. Davidowitz, 312 U.S. 52, 67 (1941); see Perez v. Campbell, 402 U.S. 637, 649 (1971).

63. It has been suggested that $\$ 28$ (a) of the Securities Exchange Act of 1934, 15 U.S.C. $\$ 78 \mathrm{bb}(\mathrm{a})$ (1976), which states that "[n]othing in this chapter shall affect the jurisdiction of the securities commission ... of any State ... insofar as it does not conflict with the provisions of this chapter," indicates that Congress implicitly accepted the prospect of concurrent federal and state tender offer regulation. This suggestion is reinforced by the failure of the Williams Act to make any explicit statement about premption. See $F$. McCaffrey, Statuloky Construction 164-67 (1953) (original act and amendment construed as one law).

Courts, however, often treat this type of saving clause as inapplicable to the precmption question. See, e.g., Pennsylvania v. Nelson, 350 U.S. 497, 501 n.10 (1956); Hirsch, supra note 59, at 538-41; Note, supra note 59, at 211-15. Moreover, as the Fifth Circuit recognized in Kidwell, the general problem of how much attention a court should pay to a saving clause is compounded by the fact that $\$ 28(\mathrm{a})$ was adopted in 1934 and was addressed to state blue sky laws, and not to tender offer laws. Great Western United Corp. v. Kidwell, 577 F.2d 1256, 1275 n.39 (5th Cir. 1978); see Hirsch, supra note 59, at 540 (questioning whether court should apply saving clause to statutory amendment enacted by later Congress). Accordingly, the entire argument against statutory preemption cannot rest on $\$ 28$ (a). It is clear, however, that there is no explicit language in any federal securities legislation that itself preempts state tender offer laws. Furthermore, $\$ 28(a)$ at least arguably creates a presumption against preemption.

64. See Hirsch, supra note 59, at 529-33; Note, supra note 55, at 625 .

65. See City of Burbank v. Lockheed Air Terminal, Inc., 411 U.S. 624, 633 (1973) ("It is the pervasive nature of the scheme of federal regulation . . . that leads us to conclude that there is pre-emption.") One commentator has relicd upon the Court's holding in Burbank to assert that the Williams Act is also so comprehensive that it allows for no supplemental state regulation. Note, supra note 7, at 1164-66. The Williams Act, howcver, unlike the Federal Aviation Agency regulations considered in Burbank, is not a detailed and comprehensive regulatory scheme; nor is it so pervasive that stricter state rules are 
Williams Act is essentially a minimum disclosure statute ${ }^{66}$ and does not attempt to deal with all aspects of a tender offer. The statute also does not depend on exclusivity for the effective protection of shareholders. In addition, even if it is assumed that the Williams Act is a pervasive regulatory scheme, the Supreme Court has recently held that preemptive intent cannot always be inferred from the "comprehensive character" of a federal law. ${ }^{67}$

A court may also infer a congressional design to preempt parallel state legislation when Congress acts in an area of dominant federal interest, even if the federal legislation is not pervasive. But the federal interest in the securities markets is not dominant; it is not comparable, for example, to the paramount federal interest in foreign affairs or national security, two areas in which the Supreme Court has rejected concurrent state legislation. ${ }^{68}$ State securities laws have traditionally stood alongside federal securities regulation, providing "a second line of protection" for investors. ${ }^{99}$ Thus, the absence of a dominant federal interest in securities regulation, evidenced by the long-recognized state role in this area, makes it inappropriate to infer that the Williams Act precludes state regulation of tender offers.

necessarily incompatible with the federal regulations. The Act simply sets out minimum disclosure standards for offerors. See Langevoort, supra note 7, at 248 . In addition, the Court was particularly concerned in Burbank that local legislation affecting airline schedules would lead to a "concomitant decrease in safety." 411 U.S. at 639 . There is no similar public safety issue in the tender offer context that would compel a finding of federal preemption.

66. See S. Rep. No. 550, 90th Cong., Ist Sess. 2-4 (1967).

67. See De Canas v. Bica, 424 U.S. 351, $359-60$ (1976) (comprehensiveness of Immigration and Nationality Act does not necessarily require preemption of California alien em. ployment statute); New York Dep't of Social Servs. v. Dublino, 413 U.S. 405, 415 (1973) (preemption not inferred from comprehensive federal work incentive provisions); Head v. New Mexico Bd. of Examiners, 374 U.S. 424, 429.30 (1963) (comprehensive nature of federal regulation under Federal Communications Act does not preempt state regulation of radio advertising).

68. See Pennsylvania v. Nelson, 350 U.S. 497, 504-07 (1956) (national security); Hines v. Davidowitz, 312 U.S. 52 (1941) (foreign affairs). In each of these cases, the Court expressed the sentiment that the state laws in question affected areas that were of vital importance to the entire nation.

69. Securities and Exchange Commission, Special Study of Securities Markets, H.R. Doc. No. 95 (pt. 4), 88th Cong., 1st Sess. 734 (1963) ("There has not been and should not be Federal preemption in the field of securities regulation.") The Supreme Court has found that "Congress, in the securities field, has not adopted a regulation system wholly apart from and exclusive of state regulation," Merrill Lynch, Pierce, Fenner \& Smith, Inc. v. Ware, 414 U.S. 117, 137 (1973), and has held that "under the securities laws state regulation may co-exist with that offered under the federal securities laws," SEC v. National Sec., Inc., 393 U.S. 453, 461 (1969). See Kaminsky v. Abrams, 281 F. Supp. 501, 504-05 (S.D.N.Y. 1968) (federal securities laws are "incomplete and interstitial" and only supersede state corporate law when there is direct conflict). 


\section{B. Operational Preemption}

When preemption is neither explicit nor implied, state law may nonetheless be preempted if it conflicts with the operation of the federal statute or produces results inconsistent with the purposes and objectives of Congress. ${ }^{70}$ This judicial determination requires a twostep analysis: the court first must construe the two statutes and then must decide whether they in fact conflict. ${ }^{71}$ The incompatibility of the two laws must be clear, however, to justify the invalidation of state regulation when Congress has not explicitly or implicitly prohibited the states from acting. ${ }^{22}$

The Supreme Court recently construed the Williams Act in Piper v. Chris-Craft Industries, Inc., ${ }^{73}$ a case involving the narrow question of whether a defeated offeror had standing to sue for money damages. Chris-Craft and the SEC both argued that in enacting the Williams Act, Congress sought to establish a policy of evenhandedness in tender offer regulation. ${ }^{74}$ Chief Justice Burger, writing for the Court, emphatically responded that "Congress was indeed committed to a policy of neutrality in contests for control, but its policy of evenhandedness does not go ... to the purpose of the legislation .... Neutrality is, rather, but one characteristic of legislation directed toward a different purpose-the protection of investors." 75 The Chief Justice recognized that "[t]he sponsors of this legislation were plainly sensitive to the suggestion that the measure would favor one side or the other in control contests; however, they made it clear that the legislation was designed solely to get needed information to the investor."76

The legislative history of the Williams Act supports the Chris-Craft

70. Castle v. Hayes Freight Lines, Inc., 348 U.S. 61, 64 (1954) (state's suspension of common carrier's right to use highways impermissibly disrupts federally authorized activities); Hill v. Florida ex rel. Watson, 325 U.S. 538, 541-42 (1945) (Florida law prescribing qualifications for union officials restricts "full freedom" that National Labor Relations Act guarantees union members); Hines v. Davidowitz, 312 U.S. 52, 67 (1941) ("Our primary function is to determine whether,... Pennsylvania's law stands as an obstacle to the accomplishment and execution of the full purposes and objectives of Congress."); see Hirsch, supra note 59, at 526-27.

71. Perez v. Campbell, 402 U.S. 637, 644 (1971).

72. The Court has cautioned that "[w]e must ... be careful to distinguish those situations in which the concurrent exercise of a power by the Federal Government and the States or by the States alone may possibly lead to conflicts and those situations where conflicts will necessarily arise." Goldstein v. California, 412 U.S. 546, 554 (1973) (emphasis in original); see Kelly v. Washington ex rel. Foss Co., 302 U.S. 1, 10 (1937) (preemption inferred only when conflict between federal and state law is so direct and positive that laws cannot be reconciled or consistently stand together).

73. 430 U.S. I (1977).

74. Id. at 29.

75. Id.

76. Id. at $30-31$. 
reasoning. It is devoid of the careful examination of the interests of the offeror and target management that would have been required in order to strike an intelligent balance between the antagonists. ${ }^{77}$ Rather, the investor remained "the constant focal point of the committee hearings." 78 SEC Chairman Cohen emphasized this orientation in his testimony before the Senate: "[T]he principal point is that we are not concerned with assisting or hurting either side. We are concerned with the investor who today is just a pawn in a form of industrial warfare. ... The investor is lost somewhere in the shuffle. This is our concern and our only concern."'79 Any balance that emerged from the Williams Act was neither a "purpose" nor an "objective" of its draftsmen, but rather a byproduct of the congressional desire to "require full and fair disclosure for the benefit of investors." 80 The fact that the state statutes may alter this balance is therefore an inappropriate basis for statutory preemption. ${ }^{81}$ Only if state regulation of tender offers conflicts with

77. Cf. Shipman, supra note 6, at 759-60 (Williams Act is not integrated national policy on takeovers and does not reflect legislative weighing of political and economic ramifications).

78. Piper v. Chris-Craft Indus., Inc., 430 U.S. 1, 31 (1977).

79. Hearings, supra note 13 , at 178 , quoted in Piper v. Chris-Craft Indus., Inc., 430 U.S. 1, 27-28 (1977) (emphasis supplied by Court).

80. 113 Cong. Rec. 24,664 (1967) (Sen. Williams).

81. Cf. Cort v. Ash, 422 U.S. 66, 80-82 (1975) (standing denied when based on subsidiary purpose of federal act).

The district court in Kidwell held that the Williams Act preempted the Idaho takeover statute because the latter destroyed "the careful balance struck in the Williams Act between the offeror and the management of the target company designed to protect the interests of the shareholders." Great Western United Corp. v. Kidwell, 439 F. Supp. 420, 437 (N.D. Tex. 1977), aff'd, 577 F.2d 1256 (5th Cir. 1978); see Langevoort, supra note 7. at 249; Note, subra note 7, at 1168-70. In affirming the district court's holding, the Fifth Circuit incorporated this concept of purposive balance, referring to the federal legislation's "neutral regulatory stance that gives each side of a tender offer an equal opportunity to persuade the investor." 577 F.2d at 1279. But, in fact, no careful balance between the offeror and the target management was purposely and affirmatively struck in the Williams Act. See Shipman, supra note 6, at 759-61 (Williams Act does not strike "carefully conceived balance" and leaves relative strength of management and offeror unchanged); Crary, Pendulum Has Swung Too Far in Support of Hostile Takeovers, N.Y.L.J., June 12, 1978, at 27, col. 1. Although it is true that Senator Williams sought "to avoid tipping the scales either in favor of management or in favor of the person making the takeover bids," 113 CoNG. REc. 24,664 (1967) (emphasis supplied), there is a crucial distinction between a desire to "avoid tipping the scales" and a deliberate attempt to establish a "neutral" balance between the competing partics.

If Congress did create a careful balance in 1968, it has quite willingly altered it on several occasions. In 1970, Congress reduced the level of stock ownership that triggers $\S 13 \mathrm{~d}$ of the Williams Act from $10 \%$ to $5 \%$. See 15 U.S.C. $\$ 78 \mathrm{~m}$ (d)(1) (1976). This alerts management to a potential tender offer at an earlier point in time. The Antitrust Improvements Act, 15 U.S.C. $\$ 18 \mathrm{a}$ (1976), has further shifted the balance in favor of management. See note 26 supra. In addition, the new schedule 14D-1, adopted by the SEC in August, 1977, makes disclosure by offerors more detailed than it had been previousiy. See p. 513 \& note 21 supra. Professor Shipman argues that "[d]uring such periods of development and uncertainty about the proper strength of federal regulation, it seems particularly appropriate to allow the states to perform their laboratory func- 
the true purpose and objective of the Williams Act-investor protection-should the state laws be held to be preempted.

The state laws have not yet been definitively construed, ${ }^{82}$ but their basic effects may be discerned with some degree of certainty. These laws require fuller disclosure than does the Williams Act, ${ }^{83}$ tend to delay tender offers, ${ }^{84}$ and generally increase the probability that offers will be unsuccessful. ${ }^{85}$ None of these effects, however, are incompatible with the Williams Act's basic objective of investor protection. The fact that the state laws require additional disclosures does not constitute a conflict; fuller disclosure tends to increase investor protection by providing the investor with more information on which to base his decision. ${ }^{80}$ This promotes the policy of the Williams Act; it certainly does not contradict it.

It is unclear whether delay injures or benefits investors in the target company. It is possible that the prospect of delay, together with the opportunity this gives incumbent management to raise defenses, might convince a potential offeror to refrain from making a tender offer, thereby depriving shareholders of the opportunity to tender their stock at a premium. This proposition, however, is entirely speculative; despite the growing number of state statutes, the use of the tender offer as a technique for seeking corporate control has "virtually exploded."

tion." Shipman, supra note 6, at 760 (footnote omitted). See generally New State Ice Co. v. Liebmann, 285 U.S. 262, 311 (1932) (Brandeis, J., dissenting) (federal system allows states to try novel social and economic experiments).

82. But see Great Western United Corp. v. Kidwell, 577 F.2d 1256, 1278-79 (5th Cir. 1978) (construing Idaho statute).

83. See p. 516 supra.

84. See p. 517 supra; Wilner \& Landy, supra note 7 , at 9-10.

85. See p. 517 supra.

86. Cf. Florida Lime \&. Avocado Growers, Inc. v. Paul, 373 U.S. 132, 141, 147-48 (I963) (minimum federal avocado standards may be supplemented by higher state standards even though state requirements had specifically been rejected by Congress). The Fifth Circuit took the opposite view in Kidwell, stating that "in the area of financial disclosure . . . 'less is more"." Great Western United Corp. v. Kidwell, 577 F.2d 1256, 1280 (5th Cir. 1978). Simultaneous compliance with the requirements of most state statutes and the Williams Act is possible without incurring liability. Subcommittee on Proxy Solicitations and Tender Offers of the Federal Regulation of Securities Committee, Amcrican Bar Association, State Takeover Statutes and the Williams Act, 32 Bus. LAw. 187, 191 (1976) [hereinafter cited as ABA REPORT]; Vaughan, supra note 31, at 974.

87. See Mishkin \& Nathan, Tender Offers Continue to Surge As New Laws and Cases Alter Tactics, N.Y.L.J., Dec. 19, 1977, at 30, col. 1; id. at 32, col. 2. A practitioner involved in many tender offers has asserted that there is no evidence that the state statutes have deterred potential offerors, see Interview with Edwin B. Mishkin, Esq. (Nov. 13, 1977) (notes on file with Yale Law Journal), and the chief of the SEC's tender offer office has stated that regardless of the state statutes, the tender offer remains the most popular means of taking over a company. Appleton, The Proposed Requirements, 32 Bus. Law. 1381, 1381 (1977). The statistics secm to support these assertions. Although there were only 269 tender offer bids between 1970 and 1975, there were 132 takeover attempts in 1976 and 181 in 1977. Austin, Study Reveals Trends in Tactics, Premiums, Success Rates in Offers, N.Y.L.J., June 12, 1978, at 25, col. 5. 
It is more likely that the main effect of delay is to benefit the investors in the target company. A longer offering period reduces the panic atmosphere engendered by tender offers and the concomitant pressure on shareholders to tender their shares immediately. ${ }^{88}$ Moreover, the longer period permits the formation of an auction market for the target's stock, ${ }^{89}$ and thus may allow the target's management to secure a higher competing bid for investors. ${ }^{90}$ Finally, to the extent that the statutes calm the panic atmosphere surrounding tender offers, the courts may hold target directors to a correspondingly higher duty to act reasonably and in the best interest of shareholders. ${ }^{91}$

The state tender offer statutes may decrease the likelihood that a tender offer, once made, will be successful. ${ }^{92}$ But this in no way conflicts with the Williams Act, the purpose of which is neither balance nor neutrality but investor protection. ${ }^{93}$ In short, the basic effects of

88. Robinson, supra note 6 , at 41 , col. 1 . It has been stated frequently that the $7-$ to 10-day offering period provided by the Williams Act, see note 26 supra, is too short for shareholders to evaluate an offer adequately. Panic selling is said to be the result. By lengthening the minimum offering period, the state statutes permit a more orderly evaluation of an offer by investors. E. ARANow, H. EINHORN \& G. BERLSTEIN, supta note 2, at 218-19; see ABA REPORT, supra note 86, at 189, 195-96.

89. See Robinson, supra note 6.

90. See Cheney, Hitchcock Scenario for Takeovers Replaces Shootout at OK Corral, N.Y.L.J., June 12, 1978, at 33, col. 3. The resulting escalation in the premium offered has been extremely beneficial to shareholders of the target company. Robinson, supra note 6; see The Great Takeover Binge, Bus. WEEK, Nov. 14, 1977, at 177 ("The simple fact is that almost all the companies that have been targets of takeover bids have eventually been gobbled up, although not always by the original bidder.") As a result, even if delay defeats the initial offeror, it is likely that a shareholder will have an opportunity to tender his stock at an even higher price. In addition, the target company's stock generally rises toward the tender price once the offer has been announced. Shipman, supra note 6, at 758; Wilner \& Landy, supra note 7, at 10. Thus, whether or not the offeror is defeated, the shareholders will benefit from the higher price and increased market for their securities.

91. Flom, Forcing a Friendly Offer, 32 Bus. LAw. 1319, 1320 (1977); cf. Electronic Specialty Co. v. International Controls Corp., 409 F.2d 937, 948 (2d Cir. 1969) (Friendly, J.) (standard of conduct to which participants in tender offer held tempered by fact that they "act ... under the stresses of the market place").

92. See pp. 517,523 supra.

93. See pp. 521-22 supra. Several commentators have asserted that the state statutcs conflict with the Williams Act and should be preempted because they impose substantive requirements that differ from those prescribed by Congress. See, e.g., E. ARANow, H. Einhorn \& G. Berlstein, supra note 2, at 226-29; Wilner \& Landy, supra note 7, at 30-31. These commentators have failed, however, to define the purpose of the Williams Act properly. Aranow, Einhorn and Berlstein, for example, suggest that by requiring the offeror to purchase all shares tendered on a pro rata basis for more than the first 10 days of the offer as required by the Williams Act, the state statutes dilute the rights of shareholders who tender during the first 10 days. It is asserted that this creates a conflict between the federal and state laws. See E. Aranow, H. Einhorn \& G. BerLstein, supra note 2 , at $226-27$. In addition, the long withdrawal periods provided by the state statutes are said to conflict with the offeror's federally provided right to treat tenders as irrevocable between the eighth and sixtieth days of the offer. Id. at 227 . But neither of these state provisions creates any actual conflict with the Williams Act; the offeror can 
state tender offer laws do not disrupt the operation of the federal statute in any way. There is thus no operational preemption, just as there is no explicit or implicit preemption. Congress could preempt these state laws, of course, but it has not yet done so.

\section{The Commerce Clause}

The state statutes have also been criticized by commentators as violative of the commerce clause of the Constitution. ${ }^{94}$ The tender offer laws are said to interfere with interstate commerce by disrupting the national securities markets, by imposing burdensome filing requirements on offerors, by regulating transactions involving shareholders who live in other states, and by effectively prohibiting the issuance of national tender offers. ${ }^{95}$ Supporters of the state laws, however, argue that these burdens are justified by the states' legitimate interest in investor protection. ${ }^{96}$

Although some of the disruptive effects of the tender offer statutes tend to be exaggerated by the commentators, there can be little doubt that the state laws do impose substantial burdens on interstate com-

certainly comply with both the federal and state laws simultaneously. More fundamentally, these preemption arguments fail to focus on the Williams Act's single goal of investor protection. The Act was not designed to protect either shareholders who tender early or offerors. Rather, it was intended to assist all investors who are confronted with a tender offer. Thus, these inconsistencies between the federal and state schemes do not justify judicial preemption of the state statutes. The contention that the state filing requirements conflict with the Williams Act because Congress rejected such provisions, see Wilner \& Landy supra note $\mathbf{7}$, at $\mathbf{2 5 - 2 9}$, is similarly unconvincing, given the absence of evidence that the state regulations have been harmful to the target company's sharcholders.

94. E.g., Wilner \& Landy, supra note 7, at 15-23; Note, supra note 7, at 1152-62.

A state law that does not conflict with and is not preempted by a federal regulatory scheme may nevertheless impose an undue burden on interstate commerce. See, e.g., Florida Lime \&: Avocado Growers, Inc. v. Paul, 373 U.S. 132 (1963) (rejecting assertion that federal regulation completely ousted state regulatory authority but remanding for determination as to whether law in question unduly burdened interstate commerce); Southern Pac. Co. v. Arizona ex rel. Sullivan, 325 U.S. 761 (1945) (rejecting preemption challenge, but holding statute violative of commerce clause).

95. See Great Western United Corp. v. Kidwell, 577 F.2d 1256, 1283-85 (5th Cir. 1978); E. Aranow, H. Einhorn \& G. Bertstein, supra note 2, at 231; Langevoort, supra note 7, at 242-46; Wilner \& Landy, supra note 7, at 15-23; Note, supra note 7, at 1152-62.

96. See, e.g., Great Western United Corp. v. Kidwell, 577 F.2d 1256, 1279, 1283 (5th Cir. 1978); Memorandum of Defendants at 33, Great Western United Corp. v. Kidwell, 439 F. Supp. 420 (N.D. Tex. 1977), aff'd, 577 F.2d 1256 (5th Cir. 1978). The purpose of investor protection underlies the state blue sky laws that protect the public from fraud in the issuance and sale of securities by supplementing the minimum requirements of the Securities Act of 1933. See L. Loss \& E. CowerT, BLUE SkY LAws 17-42 (1958). Investor protection has long been recognized as a legitimate state goal. See Hall v. Geiger-Jones Co., 242 U.S. 539, 550 (1917) (purpose of Ohio blue sky law "to protect the public against the imposition of unsubstantial schemes and the securities based upon them" is wholly within competency of state). 
merce. Nevertheless, careful and detailed commerce clause analysis is necessary, particularly since commerce clause litigation typically involves complex issues of federalism and statutory interpretation. Moreover, the Supreme Court has recently been reluctant to find conflicts between state laws and the commerce clause. Although a few statutes have been struck down, ${ }^{97}$ several others that clearly affected interstate commerce have been upheld. ${ }^{98}$ It would not be unreasonable to conclude that the overall pattern of these decisions has favored state regulation.

The test used by the Supreme Court in determining whether a state statute violates the commerce clause involves balancing the statute's impact on interstate commerce and the legitimate state interests served by the law. ${ }^{99} \mathrm{~A}$ statute will generally violate the commerce clause if it substantially impedes the free flow of commerce between the states or affects an area of commerce that requires national uniformity. ${ }^{100}$ The Court has explained, however, that "in the absence of conflicting legislation by Congress, there is a residuum of power in the state to make laws governing matters of local concern which nevertheless in some measure affect interstate commerce or even, to some extent, regulate it."101 A state law affecting or regulating interstate commerce will be upheld if it effectuates a legitimate state interest and if the burden imposed on commerce does not outweigh the statute's putative local benefits. ${ }^{102}$

It is thus necessary to determine whether the burdens imposed by tender offer statutes on interstate commerce are balanced by any

97. E.g., City of Philadelphia v. New Jersey, 98 S. Ct. 2531 (1978) (New Jersey statute prohibiting importation of solid and liquid wastes violates commerce clause); Raymond Motor Transp., Inc. v. Rice, 434 U.S. 429 (1978) (Wisconsin law barring vehicles over 55 feet long invalid under commerce clause).

98. E.g., Moorman Mfg. Co. v. Bair, 98 S. Ct. 2340 (1978) (Iowa single-factor sales formula for apportioning net income of interstate corporations, which could result in taxation of $100 \%$ of net income from products sold in Iowa but manufactured outside state, does not violate commerce clause); Exxon Corp. v. Maryland, 98 S. Ct. 2207 (1978) (upholding Maryland statute prohibiting producers or refiners of petroleum products from operating service stations in state).

99. Raymond Motor Transp., Inc. r. Rice, 434 U.S. 429, 441 (1978) (commerce clause inquiry "necessarily involves a sensitive consideration of the weight and nature of the state regulatory concern in light of the extent of the burden imposed on the course of interstate commerce"); Great Atl. \& Pac. Tea Co. v. Cottrell, 424 U.S. 366, 371.72 (1976) (when statute promoting legitimate state interest also burdens interstate commerce Court "is confronted with a problem of balance"). See generally G. GuNTHER, supra note 8, at 308-56 (summarizing evolution of balancing approach).

100. Southern Pac. Co. v. Arizona ex rel. Sullivan, 325 U.S. 761, 767 (1945).

101. Id.

102. Pike v. Bruce Church, Inc., 397 U.S. 137, 142 (1970); see Huron Portland Cement Co. v. Detroit, 362 U.S. $440,443-44(1960)$. The extent of the burden that will be tolerated depends, in part, upon whether the local interest could be promoted as well with a lesser impact on interstate commerce. 397 U.S. at 142. 
legitimate state interests. This does not mean, however, that the commerce clause test must be applied to each state statute taken as a whole, as other commentators have apparently assumed. ${ }^{103}$ The state laws consist of various components, and the validity of these components under the commerce clause differ. If the balancing test were applied to a state tender offer statute in its entirety, the burdens might well outweigh the benefits. This would lead to the statute's invalidation and the consequent elimination of the benefits it affords shareholders. It is therefore preferable to apply the commerce clause analysis to the separate provisions of the state statutes. ${ }^{10 \pm}$ Such an analysis of the state statutes indicates that if certain burdensome provisions were eliminated, the statutes could continue to protect investors without violating the requirements of the commerce clause. The analysis thus suggests possibilities both for a more focused judicial review of the tender offer statutes $^{105}$ and for state legislative reform.

The most objectionable feature of the state tender offer laws is their extraterritorial coverage. ${ }^{106}$ The extraterritorial reach of these statutes enables a state to control transactions between nonresident offerors and nonresident shareholders. ${ }^{107}$ Extensive state regulation of interstate

103. See Great Western United Corp. v. Kidwell, 577 F.2d 1256, 1285-86 (5th Cir. 1978); Wilner \& Landy, supra note 7, at 21-23; Note, supra note 7, at 1152-62.

104. Since 1917 when the Supreme Court upheld the constitutionality of the blue sky laws, see Hall v. Geiger-Jones Co., 242 U.S. 539 (1917), few attempts have been made to have an entire securities statute invalidated. In a number of cases, however, a particular clause or section has been struck down. E.g., Mulhern v. Gerold, 116 F. Supp. 22 (D. Mass. 1953) (blue sky provision providing substituted service of process upon nonresidents with no requirement of notice held unconstitutional); Miller v. Union Bank \& Trust Co., 7 Cal. 2d 31, 59 P.2d 1024 (1936) (requirement that state but not national banks secure permit before issuing certain securities violated state and federal guarantees of equal protection); see L. Loss \& E. Cowetr, supra note 96, at 13-17; cf. Wright, Correlation of State Blue Shy Laws and The Federal Securities Acts, 26 CoRNeLl L.Q. 258, 294 (1941) (arguing that constitutionality of blue sky provisions should be evaluated independently).

105. A federal court may be limited in its ability to declare some provisions of a state statute unconstitutional while affirming the legitimacy of others. The Supreme Court has explained that an otherwise valid provision of a state statute can only be treated as separable from the unconstitutional elements of the law if "it appears both that, standing alone, legal effect can be given to it and that the legislature intended the provision to stand, in case others included in the act and held bad should fall." Dorchy v. Kansas, 264 U.S. 286, 290 (1924). The job of determining the state legislature's intent, "like the usual function of interpreting a state statute, rests primarily upon the state court." Id. Several of tender offer statutes, however, include severability clauses, e.g., N.J. STAT. ANN. \$ 49:5-18 (West Supp. 1978); N.Y. Bus. CoRp. LAw $\$ 1613$ (McKinney Supp. 1977); Oho REv. Code ANN. $\$ 1707.041(1)$ (Page Supp. 1977), that would enable a federal court to conclude that the state legislature intended the various provisions of the statute to stand or fall individually. For a general discussion of the problem of severability, see P. BATOR, P. Mishkin, D. Shapiro \& H. Wechsler, Hart \& Wechsler's The Federal Courts and the Feneral SYstem 196-200 (2d ed. 1973).

106. See p. 515 supra.

107. This extraterritorial effect distinguishes the tender offer statutes from the state blue sky laws, which the Supreme Court has long recognized as fulfilling the valid state 
commerce is permissible only if such regulation effectuates a legitimate state interest. ${ }^{108}$ However, it is difficult to identify any interest supporting extraterritorial control; ${ }^{109}$ a state cannot claim that it has an interest in protecting nonresidents and in regulating transactions that take place outside the state. ${ }^{110}$ It seems more likely that the extraterritorial reach of these statutes is intended to insulate local target companies from takeovers, thereby preventing the possible liquidation or relocation of corporate assets and the consequent loss of local revenue and employment. ${ }^{111}$ Such a purpose, however, is clearly illegitimate. The Supreme Court has held that a statute may not be enacted solely to protect local economic interests. ${ }^{112}$

purpose of investor protection. See note 96 supra. Blue sky laws apply only to intrastate transactions, a fact stressed by the Court in its decision upholding the constitutionality of the Ohio blue sky law. See Hall v. Geiger-Jones Co., 242 U.S. 539, 557.58 (1917) (commerce clause challenge rejected because blue sky laws "apply to dispositions of securities within the State") (emphasis in original). In addition, several commentators have suggested that state regulation of an offer by a foreign corporation to nonresident shareholders may violate the due process clause of the Fourteenth Amendment. State jurisdiction over an offer depends primarily upon the relationship between the target company and the state. See p. 515 \& note 32 supra. Accordingly, the offeror or the offer may not have sufficient contacts with the regulating state to justify the state's exercise of jurisdiction. See E. Aranow, H. EInhorn \& G. BerLstein, supra note 2, at 231-32. This objection would be inapplicable to state tender offer statutes that only regulate sales involving resident investors, because such a limitation on the scope of the statute ensures that the transaction is adequately connected to the regulating state.

108. See p. 526 \& note 102 supra.

109. But see Shipman, supra note 6 , at $744-45$ (arguing that extraterritorial regulation by target company's state of incorporation is justified by state's right to regulate corporation's internal affairs). Shipman's attempt to draw an analogy between tender offers and classical internal affairs transactions such as proxy contests and mergers has been criticized by several commentators. See, e.g., Wilner \& Landy, supra note 7, at 16-17; Note, supra note 7 , at $1153-55$.

110. See Baldwin v. G.A.F. Seelig, Inc., 294 U.S. 511, 521 (1935) ("New York has no power to project its legislation into Vermont by regulating the price to be paid in that state for milk acquired there"). The extraterritorial regulation of interstate commerce cannot be justified on the ground that the laws of a regulating state could otherwise be circumvented by excepting the residents of that state from the offer. See p. 515 \& note 34 supra. In Baldwin, the Supreme Court dealt with an analogous question. The New York statute under review was intended to promote the economic welfare of New York's milk farmers and the quality of the milk consumed by the state's residents. New York regulated the price paid to farmers in Vermont for milk that was to be sold to consumers in New York in order to keep the New York regulatory scheme unimpaired by competition from neighboring states. Although the Supreme Court accepted the underlying purpose of the New York law, see Nebbia v. New York, 291 U.S. 502 (1934), it nevertheless found the statute unconstitutional because of its extraterritorial reach. 294 U.S. at $519,521-23$.

Even if an offeror avoided the shareholders of a particular state, those shareholders could still tender on the open market at only a fraction less than the tender price. See E. ARANow \& H. EInhorn, supra note 2, at 157-58.

111. See, e.g., Wilner \& Landy, supra note 7, at 18-19; Note, supra note 7, at 1159 .

112. Boston Stock Exch. v. Tax Comm'n, 429 U.S. 318, 329 (1977) (quoting Dean Milk Co. v. Madison, 340 U.S. 349,356 (1951)) ("Permitting the individual States to enact laws that favor local enterprises at the expense of out-of-state businesses 'would invite a mul- 


\section{Tender Offer Statutes}

The basic state interest in securities regulation is the the protection of resident shareholders. ${ }^{113}$ State tender offer regulations can permissibly promote this legitimate local interest only if they are limited to the protection of state residents and the regulation of essentially intrastate transactions. Such limitations would allow the states to satisfy the fundamental commerce clause requirement of a local interest while alleviating the impact of the statutes on interstate commerce. ${ }^{114}$

Even if this modification were implemented, it would still be necessary to determine which of the state provisions actually protect investors or further other legitimate state interests without unduly burdening interstate commerce. Disclosure requirements and regulations designed to provide shareholders with adequate time to consider offers are the most clearly acceptable features of the state statutes. These provisions do not impose an excessive burden on interstate commerce. Complying with numerous disclosure laws may be a tedious and time-consuming process ${ }^{115}$ but this type of compliance is not unlike what corporations are required to do in order to make a national stock offering. ${ }^{116}$ In addition, different states require essentially the same information; ${ }^{117}$ thus, multistate disclosure requirements should not impermissibly disrupt tender offers. Similarly, providing residents of different states with different offering periods may be painstaking and bothersome, but it is not an insurmountable obstacle for an of-

tiplication of preferential trade areas destructive' of the free trade which the Clause protects."); Foster-Fountain Packing Co. v. Haydel, 278 U.S. 1, 13 (1928) (Louisiana may not prohibit interstate movement of raw shrimp in attempt to favor local packing industries).

Even if a legitimate local purpose is found for the extraterritorial reach of the state statutes, significant burdens are still imposed on an offeror by the inevitable conflicts between the regulations of the sereral states that may assert jurisdiction over an offer. For example, Hawaii requires that an offer remain open for no more than 35 days, HawaII REv. STAT. $\$$ 417E-2(1) (1976), but Massachusetts demands that an offer remain open for a minimum of 60 days, Mass. ANN. Laws ch. 110C, $\$ 7$ (Michic/Law. Co-op Supp. 1978). Thus it is doubtful that the extraterritorial provisions could survive the commerce clause balancing test.

113. See p. 525 supra.

114. See E. ARANow \& H. Einhorn, supra note 2, at 157 (effect on interstate commerce would have been minimal if states had followed traditional blue sky approach); $\mathrm{E}$. ARANow, H. EINHORN \& G. BERLSTEIN, supra note 2, at 231 (statutes might be constitutional if they regulated only local incidents of interstate commerce).

115. See E. Aranow, H. Einhorn \& G. Berlstein, supra. note 2, at 220.

116. See L. Loss \& E. CowetT, supra note 96, at 89-95; Millonzi, Concurrent Regulation of Interstate Securities Issues: The Need for Congressional Reappraisal, 49 VA. I. REv. 1483, 1489 (1963); Wright, supra note 104, at 275-76. The complexity involved in making a national stock offering has also led to numerous, although unanswered, calls for federal premption of state blue sky laws. See Cowett, Federal-State Relationships in Securities Regulation, 28 Gro. WASH. L. REv. 287, 290 (1959); Millonzi, supra, at 1498-99.

117. E. Aranow, H. Einhorn \& G. Berlstein, supra note 2, at 212. 
feror. ${ }^{118}$ Whatever burden is imposed on commerce by these various provisions is certainly not excessive in relation to the enormous benefits of eliminating the pressure on shareholders to make hasty, uninformed decisions when confronted with "Saturday Night Special" tender offers ${ }^{119}$ and of ensuring that resident shareholders have the opportunity to receive the full value of their stock from either the initial or a later offeror. ${ }^{120}$

State regulations that deal with pro rata purchase requirements also would not be unduly burdensome since they impose no additional administrative expenses on the offeror beyond those associated with the offering period requirements. ${ }^{121}$ Moreover, these regulations also seem to be aimed at investor protection. They generally extend the period during which the offeror must purchase all shares on a pro rata basis ${ }^{122}$ and thereby assure the shareholder that his stock will not be rejected by the offeror because the desired number of shares has already been tendered. ${ }^{123}$ Thus, these regulations, like those that extend the minimum offering period, decrease the pressure on shareholders to tender immediately and permit a more orderly evaluation of tender proposals. ${ }^{124}$ It seems likely, then, that these provisions also satisfy the commerce clause balancing test.

The state regulations addressed to shareholder withdrawal rights are more problematic. They would impose substantially the same administrative burdens on the offeror as would the minimum offering period and pro rata purchase requirements, but they might also increase the offeror's uncertainty in evaluating the likelihood of the offer's success. ${ }^{125}$ However, there is a definable benefit provided shareholders by these provisions that could constitute a legitimate state pur-

118. The primary effects of these provisions would be to require the offeror to structure the offer differently in different states. The offeror could accomplish this by including in all tender offer solicitations a reference to the various offering periods available to residents of the different states and by treating all tendered shares accordingly. The overall effect, however, would be to increase the offeror's administrative costs.

119. See note 88 supra.

120. See p. 524 supra.

121. See note 118 supra.

122. See p. 516 supra.

123. See E. Aranow, H. Einhorn \& G. BerLstein, supra note 2, at 215.

124. See note 88 supra.

125. Many offers are structured so that the offeror is not obligated to purchase any shares unless a predetermined percentage of the target's stock is tendered. Multiple and inconsistent state withdrawal regulations, however, many of which permit withdrawal for most of the offering period, see note 45 supra, may make it difficult for the offeror to predict how many shares will remain available for purchase in the coming weeks. Thus, an offeror may find it difficult to evaluate his overall chances for success in the midst of the tender offer and to decide whether to change the terms of the offer or to discontinue the offer altogether and minimize the expenses associated with a takeover attempt. 
pose. Extended withdrawal periods benefit unsophisticated shareholders who often tender early, in contrast to more experienced investors who typically tender as late as possible in the hope of profiting from a higher competing offer. ${ }^{126}$ The protection of unsophisticated investors is certainly a desirable objective; ${ }^{127}$ however, the benefits derived from the provision of extended withdrawal rights are not as widespread as those that result from the disclosure and offering period requirements, which benefit all resident shareholders. Thus, it is probable that these provisions would not survive the commerce clause balancing test.

Other state statutory provisions more clearly violate the commerce clause because they tend to impose a greater burden on interstate commerce and are less justifiable on the basis of the states' interest in shareholder protection. Those state statutes that allow the target to demand a hearing are particularly troublesome. ${ }^{128}$ The target's management could invoke these provisions to obstruct a national tender offer endlessly; ${ }^{129}$ the prospect of fifty simultaneous hearings might well deter most offerors. Moreover, such hearings are unlikely to provide much protection for shareholders. It is the target's management that initiates the challenge, and management's goals are likely to be different from those of shareholders, particularly at the time of a tender offer. ${ }^{130}$ It would thus be fundamentally inconsistent with the requirements of the commerce clause to permit the target company to challenge the adequacy of the offeror's disclosures in numerous state proceedings. ${ }^{131}$

State tender offer regulations that require that the target company's management be given advance notification of the impending offer also seem to be more protective of management than of shareholders. ${ }^{132}$ This warning period may be used by management to develop and

126. See ABA Report, supra note 86 , at 195 .

127. Cf. Nevada Legislative Comm'n of the Legislative Council Bureau, Consumer Protection Bulletin No. 91, at 12-15 (1970) (discussing need for state legislation to protect unsophisticated consumers).

128. See p. 516 supra.

129. See note 40 supra.

130. The jobs of the target company's executives are generally threatened by a tender offer for the company. See Wilner \& Landy, supra note 7, at 18-19. Thus, although the shareholders may relish the opportunity to tender their stock at the offered price, management may use the state statutes and the hearing provisions to thwart the offeror. See E. Aranow \& H. Einhorn, supra note 2, at 265-66. But see E. Aranow, H. Einhorn \& G. BerLsteIn, supra note 2, at 82 (promises of future employment may give management an interest in success of offer).

131. Of course, state regulators would not be limited in their ability to protect shareholders' interests if an offeror failed to comply fully with the state's requirements. See p. 516 supra.

132. See p. 516 \& note 39 supra. 
implement a defensive strategy in order to defeat the offeror. ${ }^{133}$ If management is successful, the offer may never become effective, and shareholders will not have the opportunity to tender their stock. ${ }^{134}$ Since protecting incumbent management is an illegitimate state purpose, it is unlikely that the advance notification requirements comport with the requirements of the commerce clause.

\section{Conclusion}

The decision in Great Western United Corp. v. Kidwell ${ }^{135}$ suggests that any state tender offer statute that strikes a balance between the offeror and incumbent management different from that reached by the Williams Act is preempted. The Fifth Circuit concluded that Congress deliberately chose to maintain a neutral stance in the regulation of tender offers and that the Idaho statute was preempted because it disrupted this neutrality. ${ }^{136}$ The court failed to recognize, however, that the "sole purpose" of the Williams Act is to protect investors; ${ }^{137}$ unless a state tender offer law conflicts with this congressional objective it is not preempted. Since there is little evidence to suggest that the state acts operate to the detriment of investors, these acts are apparently valid under the supremacy clause.

The Fifth Circuit also held that the Idaho takeover law violated the commerce clause; ${ }^{138}$ and, taken as a whole, the Idaho statute may indeed be unconstitutional. Yet the states do have a legitimate interest in protecting their investors, and not all of the state regulations are necessarily invalid under the commerce clause. To ensure that its tender offer statute is constitutionally permissible, a state must consider each regulation individually and determine first, whether it effectuates a legitimate state interest, and second, whether its putative benefits justify the burden it imposes on interstate commerce. By eliminating those provisions that fail to satisfy these fundamental requirements, a state can constitutionally protect resident shareholders who are confronted with a tender offer.

133. See p. 517 supra.

134. For example, the target may arrange a defensive merger or block the offer in the courts before its shareholders are given a chance to tender their stock. See note 50 supra.

195. 577 F.2d 1256 (5th Cir. 1978).

136. Id. at 1279.80 .

137. Piper v. Chris-Craft Indus., Inc., 430 U.S. 1, 30-31 (1977).

138. 577 F.2d at 1286. 